\title{
超高層建物のアクティブブレース付加による制振および最適配置法の検討 VIBRATION CONTROL OF HIGH-RISE BUILDING USING ACTIVE BRACES AND THEIR OPTIMAL PLACEMENT
}

\author{
上田 実乃里*1, 三浦 奈々子*2, 曾 根 彰*3
}

Minori UEDA, Nanako MIURA and Akira SONE

\begin{abstract}
In this paper, an optimal placement of active braces for a high-rise building is researched. From the elements of the feedback gain matrix given by a Linear Quadratic Regulator (LQR) method, it is confirmed that control forces become large at the layers which story drifts are large. Thus, two placements of active braces, which are decided from the mode shape, are proposed. And it is shown that the proposed placements suppress building responses effectively, and they are safer when an active brace was broken because they keep more active braces around broken point.
\end{abstract}

\section{Keywords : High-risebuilding, Adtivebrace, Long period earthquake, Lin€ar quadratic regulator, Vibration control}

高層建物，アクティブブレース，長周期地震動，線形二次レギュレータ，制振

\section{1. 緒言}

現在日本には多くの超高層建物が存在しており，これらの建物は 変形により地震のエネルギーを吸収する仕組みになっている。また 建物の固有周期は建物高さにおおよそ比例して長周期化するため, 超高層建物は通常の地震であれば共振を起こしにくいが，長周期地 震動を受けた場合には，共振を起こし大きく変形する摇れが長時間 継続することが予想される.

2004 年 10 月 23 日に発生した新潟県中越地震では, 震源地から 約 $200 \mathrm{~km}$ 離れた新宿区において高層および超高層建物が共振をお こし, エレベータのロープ等が昇降路内の機器に絡まるなどの不具 合が発生した ${ }^{1)}$.また，2011 年の東北地方太平洋沖地震では，震源 から約 $770 \mathrm{~km}$ 離れた大阪の超高層建物が約 10 分間にわたり摇れ 続け, 最上階における摇れ幅は最大で約 $2.7 \mathrm{~m}$ に及んだ ${ }^{2)}$.よって, 超高層建物の振動対策は重要な課題である.

制振補強技術のうち，特に高い制振効果が期待できるアクティブ 方式制振装置の代表的なものの一つとして，アクティブブレースが あげられる。アクティブブレースに関する研究として，構造系と制 御系の同時最適設計手法が研究されており, Tzan and Pantelides ${ }^{3}$ は，不確定な地震動入力のモデルとして energy-bound convex model を提案し， 1 ・ 2 層にアクティブブレースを有する 10 層建物 に最適設計を適用しており，Cimellaroら ${ }^{4)} 2$ 段階の設計を行う redesign approach を提案し, 線形二次レギュレータ（LQR）で制 御されたアクティブブレースを 9 層建物に適用しており，入力波に は白色雑音を用いている。また, Cimellaro ら 5)は同手法を弾塑性
応答を考慮した場合に応用し，スライディングモード制御されたア クティブブレースを各層に有する 8 層建物に適用しており，入力波 には 1940 年に観測された El Centro 波を用いている.小檜山・堀 口 6) は PD 制御されたアクティブブレースを有する 3 層建物の線形 弾性 3 質点系モデルを対象に同時最適化を行い，入力波には告示 1461 号のまれに発生する地震動に対する応答スペクトルに適合し た模擬地震動を用いている.

このように,アクティブブレースに関する研究は複数存在するが, その多くは 10 層程度の高層建物を想定しており, 超高層建物に組 み込んだ例はそれほど多くない，超高層建物を対象とする場合，建 物の大型化に伴う装置数の増加および高コスト化が予想されること から，パッシブなブレース同様，その配置も同時に考える必要があ ると考えられる。 また，入力波としては白色雑音や El Centro 波が 多く用いられており, 長周期地震動に関する研究は少ない.

本論では, 長周期地震動で問題となる周期帯を含む広い周期帯域 で安定した応答低減, および故障に対するロバスト性の高い最適配 置決定のための初期検討として, 超高層建物の振動モードに基づい た配置方法を提案することを目的とする．また，超高層建物におい て全層あるいは多量の層に対してアクティブブレースを付加するこ とは現実的でない，そこで，限られたブレース数で効果的な振動抑 制効果を実現するブレースの配置方法を検討する.
*1 京都工芸繊維大学大学院工芸科学研究科 大学院生

*2 京都工芸繊維大学機械工学系 助教・博士 (工学)

*3 京都工芸繊維大学機械工学系 教授·工博
Grad. Student, Dept. of Mechanical Engineering, Kyoto Institute of Technology Assist. Prof., Faculty of Mechanical Engineering, Kyoto Institute of Technology, Dr.Eng. Prof., Faculty of Mechanical Engineering, Kyoto Institute of Technology, Dr.Eng. 


\section{2. 解析モデル}

\section{1 超高層建物のモデル化}

本研究では, Fig. 1 に示すような $N$ 層からなる超高層建物モデル を使用する。なお，解析対象の上下および回転方向の振動の影響は 無視し，水平せん断方向の振動のみを考慮したモデルとする。建物 モデルは線形モデルとし，この運動方程式は，次のようになる。

$$
\begin{aligned}
& \mathbf{M} \ddot{\mathbf{x}}(\mathrm{t})+\mathbf{C} \dot{\mathbf{x}}(\mathrm{t})+\mathbf{K} \mathbf{x}(\mathrm{t})=-\mathbf{M}\{1\} \ddot{x}_{\mathrm{g}}(\mathrm{t})+\mathbf{f u}(\mathrm{t}) \\
& \mathbf{M}=\left[\begin{array}{ccccc}
\mathrm{m}_{1} & & & & \mathbf{O} \\
& \ddots & & & \\
& & \mathrm{m}_{\mathrm{i}} & & \\
& & & \ddots & \\
\mathbf{O} & & & & \mathrm{m}_{\mathrm{N}}
\end{array}\right] \\
& \mathbf{C}=\left[\begin{array}{ccccccc}
c_{1}+c_{2} & -c_{2} & & & & & \text { O } \\
-c_{2} & c_{2}+c_{3} & -c_{3} & & & & \\
& & \ddots & & & & \\
& & -c_{i} & c_{i}+c_{i+1} & -c_{i+1} & & \\
& & & & \ddots & & \\
& & & & -c_{N-1} & c_{N-1}+c_{N} & -c_{N} \\
\mathbf{O} & & & & & -c_{N} & c_{N}
\end{array}\right] \\
& \mathbf{K}=\left[\begin{array}{ccccccc}
k_{1}+k_{2} & -k_{2} & & & & & \text { O } \\
-k_{2} & k_{2}+k_{3} & -k_{3} & & & & \\
& & \ddots & & & & \\
& & -k_{i} & k_{i}+k_{i+1} & -k_{i+1} & & \\
& & & & \ddots & & \\
& & & & -k_{N-1} & k_{N-1}+k_{N} & -k_{N} \\
\text { O } & & & & & -k_{N} & k_{N}
\end{array}\right] \\
& \mathbf{x}(\mathrm{t})=\left[\begin{array}{lllll}
\mathrm{x}_{1}(\mathrm{t}) & \cdots & \mathrm{x}_{\mathrm{i}}(\mathrm{t}) & \cdots & \mathrm{x}_{\mathrm{N}}(\mathrm{t})
\end{array}\right]^{\top} \\
& \{1\}=\left[\begin{array}{lll}
1 & \cdots & 1
\end{array}\right]^{\top}
\end{aligned}
$$

本論では， I は単位行列， O は零行列として用いる。 M , C , K , $\mathbf{x}(\mathrm{t}) ， \mathbf{f} ， \mathbf{u}(\mathrm{t})$ はそれぞれ解析対象全体での質量行列, 減衰行列, 剛性行列, 地表面に対する相対変位ベクトル, 制御力の分配行列, 制御力ベクトルである。 $x_{\mathrm{g}}$ は地表面の絶対変位, $\mathrm{h}$ は層の高さ， $x_{\mathrm{i}}$ は地表面に対する第 $\mathrm{i}$ 層の相対変位である。 $\mathrm{m}_{\mathrm{i}} ， \mathrm{c}_{\mathrm{i}} ， \mathrm{k}_{\mathrm{i}}$ はそれぞれ 各層の質量, 減衰係数, および層剛性である。 $\mathrm{u}_{\mathrm{i}}$ はアクティブブレ ースにより第 $\mathrm{i}$ 層および第 i - 1 層に付加される制御力（|u $\mid \leq 1000 ）$ である。

第 $\mathrm{i}$ 層の層剛性 $\mathrm{k}_{\mathrm{i}}$ の分布は $\mathrm{A}_{\mathrm{i}}$ 分布により与え, 建物の減衰は剛性 比例型とし, 第 $\mathrm{i}$ 層の減衰係数 $\mathrm{c}_{\mathrm{i}}$ を建物の 1 次固有円振動数 $\omega_{1}$ と減 衰定数 $を$ 用いて次式で与える.

$$
c_{i}=\frac{2 \varsigma \mathrm{k}_{i}}{\omega_{1}} \quad(i=1,2, \cdots N)
$$

\section{2 アクティブブレースの配置による行列の変化}

行列 $\mathbf{f}$ および $\mathrm{u}$ は，全層にアクティブブレースを配置する場合に は次式のようになる.

$$
\begin{gathered}
\mathbf{f}=\left[\begin{array}{cccc}
1 & -1 & & \mathbf{O} \\
& \ddots & \ddots & \\
& & \ddots & -1 \\
\mathbf{O} & & & 1
\end{array}\right] \\
\mathbf{u}(\mathrm{t})=\left[\begin{array}{lllll}
\mathrm{u}_{1}(\mathrm{t}) & \cdots & \mathrm{u}_{\mathrm{i}}(\mathrm{t}) & \cdots & \mathrm{u}_{\mathrm{N}}(\mathrm{t})
\end{array}\right]^{\top}
\end{gathered}
$$

これらの行列はアクティブブレースの配置により変化し，例とし て第 $\mathrm{i}$ 層にアクティブブレースを配置しない場合には，式(8)の i 列 に含まれる要素をす心゙て 0 に置き換えることでこれを表すことがで きる。

\section{3 パラメータの設計}

解析に用いるパラメータを Table 1 に示す. 建物モデルのパラメ 一タは， $250 \mathrm{~m}$ 級の過去の地震において被害が報告されている実在 建築物を参考に設定した.また, 構造種別は鉄骨造を想定しており, このモデルの 2,3 次の固有周期はそれぞれ $2.2 \mathrm{~s}, 1.4 \mathrm{~s}$ である.

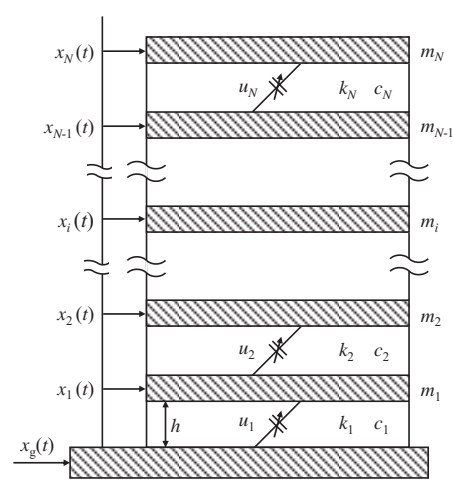

Fig. 1 Analysis Model

Table 1 Parameters of the building model

\begin{tabular}{lcc}
\hline Parameter & Symbol & Value \\
\hline \hline Story height & $\mathrm{h}$ & $4.0 \mathrm{~m}$ \\
Number of stories & $\mathrm{N}$ & 60 \\
Fundamental natural period & $\mathrm{T}_{1}$ & $5.8 \mathrm{~s}$ \\
Damping factor & $\zeta$ & 0.01 \\
Mass of each story & $\mathrm{m}_{\mathrm{i}}$ & $2.0 \times 10^{6} \mathrm{~kg}$ \\
\hline
\end{tabular}

3. 最適レギュレータ法

制御則に関しては，最適レギュレータ， $\mathrm{H}_{2}$ 制御， $\mathrm{H}_{\infty}$ 制御，スラ イディングモード制御，ファジースライディングモード制御や可変 構造制御など, 多様な手法が建物の振動制御に対して提案・適用さ れている。これらの中で実用化した制振装置の制御則の多くはフィ ードバック制御であり，制御理論としては最適レギュレータまたは ロバスト制御が用いられている。そこで，本論では制御入力の決定 に最適レギュレータ法を使用し，建物の全層の絶対加速度応答を制 御目的とする。また，本論では制御遅れについては考慮せず，制御 力の決定後時差なく制御が行われるものとする. 式(1)の運動方程式 を，状態空間表現を用いて書き換えると，以下のようになる. 


$$
\begin{gathered}
\dot{\mathbf{X}}(\mathrm{t})=\mathbf{A} \mathbf{X}(\mathrm{t})+\mathbf{B u}(\mathrm{t})+\mathbf{G} \ddot{\mathbf{X}}_{\mathrm{g}}(\mathrm{t}) \\
\mathbf{X}(\mathrm{t})=\left[\begin{array}{ll}
\mathbf{x}(\mathrm{t})^{\top} & \dot{\mathbf{x}}(\mathrm{t})^{\top}
\end{array}\right]^{\top} \\
\mathbf{A}=\left[\begin{array}{cc}
\mathbf{O}_{\mathrm{N} \times \mathrm{N}} & \mathbf{I}_{\mathrm{N} \times N} \\
-\mathbf{M}^{-1} \mathbf{K} & -\mathbf{M}^{-1} \mathbf{C}
\end{array}\right] \\
\mathbf{B}=\left[\begin{array}{c}
\mathbf{O}_{\mathrm{N} \times \mathbf{N}} \\
\mathbf{M}^{-1} \mathbf{f}
\end{array}\right] \\
\mathbf{G}=\left[\begin{array}{c}
\mathbf{O}_{\mathrm{N} \times \mathrm{N}} \\
-\mathbf{I}_{\mathrm{N} \times \mathrm{N}}
\end{array}\right]
\end{gathered}
$$

式(1)を変形することによって, 建物の全層の絶対加速度 $\mathbf{y}_{\mathrm{a}}(\mathrm{t})$ は 状態ベクトル $\mathbf{X}(\mathrm{t})$ を用いて次式で表される7).

$$
\begin{aligned}
& \mathbf{y}_{a}(\mathrm{t})=\ddot{\mathbf{x}}(\mathrm{t})+\{1\} \ddot{\mathrm{x}}_{\mathrm{g}}(\mathrm{t}) \\
& =\left[\begin{array}{ll}
-\mathbf{M}^{-1} \mathbf{K} & -\mathbf{M}^{-1} \mathbf{C}
\end{array}\right] \mathbf{X}(\mathrm{t})+\mathbf{M}^{-1} \mathbf{f u}(\mathrm{t}) \\
& =\mathbf{C}_{\mathrm{ss} \text { a }} \mathbf{X}(\mathrm{t})+\mathbf{D}_{\mathrm{ss} \text { a }} \mathbf{u}(\mathrm{t}) \\
& \mathbf{C}_{\text {ss_a }}=\left[\begin{array}{ll}
-\mathbf{M}^{-1} \mathbf{K} & -\mathbf{M}^{-1} \mathbf{C}
\end{array}\right] \\
& \mathbf{D}_{\text {ss a }}=\mathbf{M}^{-1} \mathbf{f}
\end{aligned}
$$

したがって，建物の全層の絶対加速度 $\mathbf{y}_{\mathrm{a}}(\mathrm{t})$ を制御目的とした場 合の評価関数は次式となる.

$$
\begin{aligned}
& J=\int_{0}^{\infty}\left[\mathbf{y}_{\mathrm{a}}^{\top}(\mathrm{t}) \mathbf{y}_{\mathrm{a}}(\mathrm{t})+\mathbf{u}^{\top}(\mathrm{t}) \mathbf{I R} \mathbf{u}(\mathrm{t})\right] \mathrm{dt} \\
& =\int_{0}^{\infty}\left[\mathbf{X}_{\boldsymbol{\top}}^{\top}(\mathrm{t}) \mathbf{Q}_{\mathrm{a}} \mathbf{X}(\mathrm{t})+2 \mathbf{X}_{\top}^{\top}(\mathrm{t}) \mathbf{S}_{\mathrm{a}} \mathbf{u}(\mathrm{t})+\mathbf{u}^{\top}(\mathrm{t}) \mathbf{R}_{\mathrm{a}} \mathbf{u}(\mathrm{t})\right] \mathrm{dt} \\
& \mathbf{Q}_{\mathrm{a}}=\mathbf{C}_{\mathrm{sS}}^{\top} \mathbf{C}_{\mathrm{sS} \text { a }} \\
& \mathbf{S}_{\mathrm{a}}=\mathbf{C}_{\mathrm{ss} \_\mathrm{a}}^{\mathrm{T}} \mathbf{D}_{\text {ss } \_\mathrm{a}} \\
& \mathbf{R}_{\mathrm{a}}=\mathbf{I R}+\mathbf{D}_{\mathrm{ss} \_\mathrm{a}}^{\top} \mathbf{D}_{\mathrm{ss}_{\_}}
\end{aligned}
$$

ここで， $\mathbf{Q}_{\mathrm{a}} ， \mathbf{S}_{\mathrm{a}}, \mathbf{R}_{\mathrm{a}}$ はそれぞれ重み係数行列である. 重み係数 行列の傾向としては， $\mathbf{Q}_{\mathrm{a}}$ を大きくとれば制御性能が増し， $\mathbf{R}_{\mathrm{a}}$ を大 きくとれば制御入力が小さくなる．本論文では， R によって $\mathbf{R}_{\mathrm{a}}$ の大 きさを変更している. 最適制御入力は式(22)によって与えられる. F はフィードバックゲイン行列, P は式(24)のリカッチ型代数方程式 の解である.

$$
\begin{gathered}
\mathbf{u}(\mathrm{t})=-\mathbf{F} \mathbf{X}(\mathrm{t}) \\
\mathbf{F}=\mathbf{R}_{\mathrm{a}}^{-1}\left(\mathbf{S}_{\mathrm{a}}^{\top}+\mathbf{B}^{\top} \mathbf{P}\right)
\end{gathered}
$$

$\mathbf{P}\left(\mathbf{A}-\mathbf{B R}_{\mathrm{a}}{ }^{-1} \mathbf{S}_{\mathrm{a}}{ }^{\top}\right)+\left(\mathbf{A}-\mathbf{B R}_{\mathrm{a}}{ }^{-1} \mathbf{S}_{\mathrm{a}}{ }^{\top}\right)^{\top} \mathbf{P}-\mathbf{P B R}_{\mathrm{a}}{ }^{-1} \mathbf{B}^{\top} \mathbf{P}+\mathbf{Q}_{\mathrm{a}}-\mathbf{S}_{\mathrm{a}} \mathbf{R}_{\mathrm{a}}{ }^{-1} \mathbf{S}_{\mathrm{a}}{ }^{\top}=\mathbf{O}$

\section{4. 効果的な配置法の傾向分析}

\section{1 正弦波を用いた配置法の比較}

効果的なアクティブブレースの配置法の検討のため, 上層集中配 置 (Upper)，下層集中配置 (Lower)，中層集中配置 (Middle)，等 間隔配置（Uniform）の 4 種類の配置法を用意し，解析モデルの 1 ３ 次の固有周期に同調した正弦波を入力して有効配置の傾向を調 べた，正弦波は最大速度が $25 \mathrm{~cm} / \mathrm{s}$ となるように，次式により作成 した.ここで $\omega_{\mathrm{n}}$ は $\mathrm{n}$ 次の固有角振動数である.

$$
\ddot{x}_{\mathrm{g}}=0.25 \omega_{\mathrm{n}} \sin \omega_{\mathrm{n}} \mathrm{t}
$$

なお，制御力は各正弦波を入力した場合に，最大制御力が $1000 \mathrm{kN}$ を超過しないよう，それぞれ制御力の重み $\mathrm{R}$ を与えいる.アクテ イブブレースの配置数条件については，過剩な配置数では配置によ る効果の差異が不明瞭になることが考えられるため, 本論では総数 を 10 基とする. 各配置法について, アクティブブレースを配置し た層を Table 2 にまとめる.

各配置法における加速度および層間変形角の最大值と最大制御力 を Fig. 2〜 Fig. 4 に示す.

最大応答の比較について, Fig. 2 ，Fig. 3 の(a)，(b)より 1 次およ び 2 次の正弦波においては配置法による違いがほとんど見られず, Fig. 4 の(a), (b)より 3 次の正弦波においては応答低減効果の違いが 確認できる.これは 3 次の振動モードで振動するとき, 腹や節の数 の影響で層毎の最大応答において差が大きくなったためと考えられ る。層毎の応答にばらつきの大きい 3 次正弦波においては層間変位 の大きい層へのアクティブブレースの配置の有無による影響が大き くなったと考えられる.

Table 2 Placement of active braces

\begin{tabular}{|l|l|}
\hline Upper & $51,52,53,54,55,56,57,58,59,60$ \\
\hline Lower & $1,2,3,4,5,6,7,8,9,10$ \\
\hline Middle & $26,27,28,29,30,31,32,33,34,35$ \\
\hline Uniform & $1,7,13,19,25,31,37,43,49,55$ \\
\hline
\end{tabular}

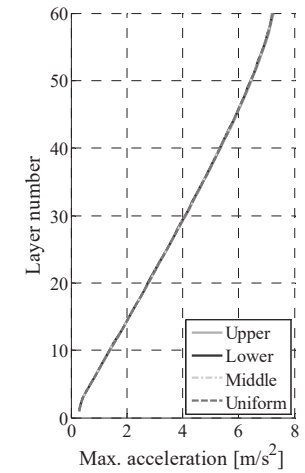

(a) Max. acceleration
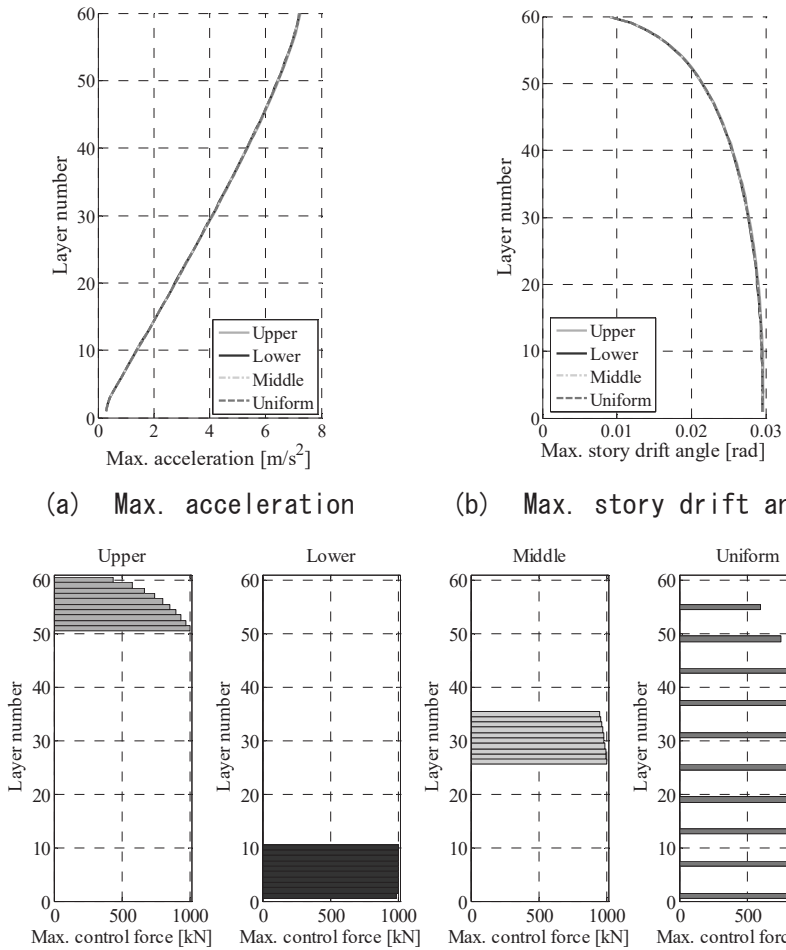

(b) Max. story drift angle

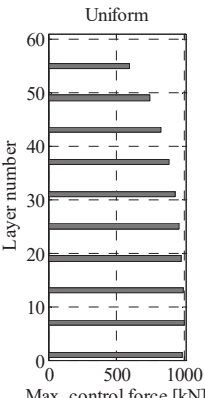

(c) Max. control force
Fig. 2 Results of maximum values (1st mode sine wave) 


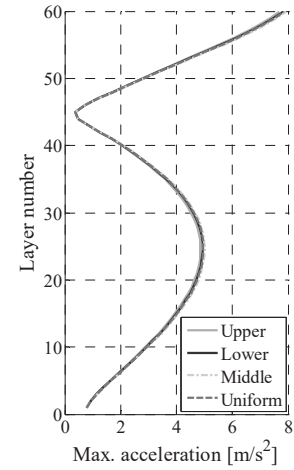

(a) Max. acceleration

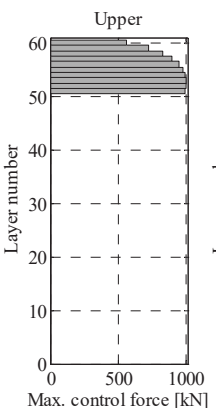

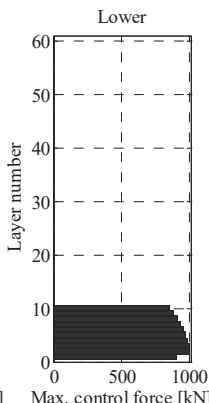

(c) Max. control force

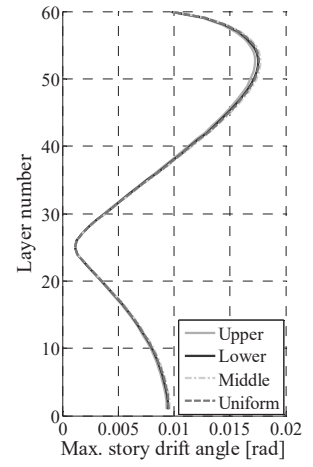

(b) Max. story drift angle
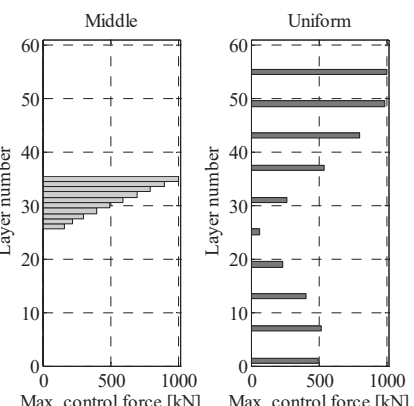

Max. control force $[\mathrm{kN}]$
Fig. 3 Results of maximum values (2nd mode sine wave)

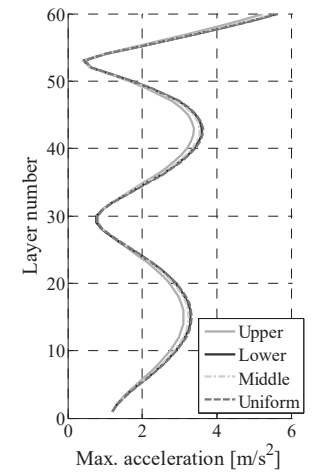

(a) Max. acceleration
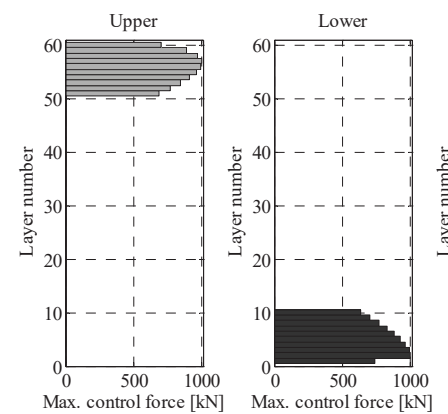

(c) Max. control force

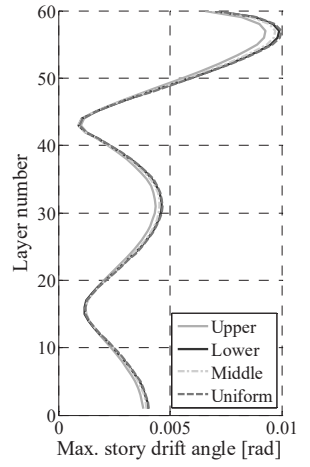

(b) Max. story drift angle
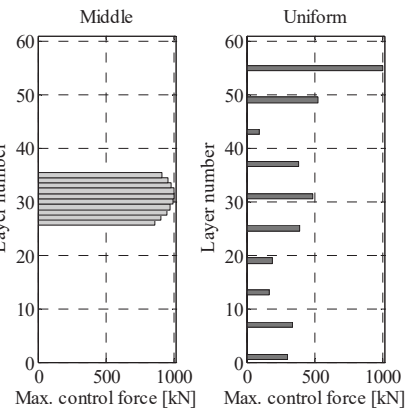

Fig. 4 Results of maximum values (3rd mode sine wave)

また，Fig. 2〜Fig. 4 の(b)と (c)を見ると，各配置法における(b)層 間変形角と (c) 最大制御力のグラフがほぼ同一の層においてピーク を取っており, アクティブブレースの制御力は層間変形角の大きな 層において大きな值を取るのではないかと予想される.

\section{2 フィードバックゲイン行列の構成}

ここでは 4.1 節で示した傾向とフィードバックゲイン行列の関 係について示す.

まず，制御力を決定するフィードバックゲイン行列 $\mathrm{F}$ がどのよう な值となっているのかを示す．制御力は式(22)によって求めること ができ, これを変位に依存する成分と速度に依存する成分に分けて 次のようにおく.

$$
\begin{gathered}
\mathbf{u}=-\mathbf{F X}=-\mathbf{F}\left[\begin{array}{ll}
\mathbf{x}^{\top} & \dot{\mathbf{x}}^{\top}
\end{array}\right]^{\top}=-\left[\begin{array}{ll}
\mathbf{F}_{\mathrm{x}} & \mathbf{F}_{\mathrm{v}}
\end{array}\right]\left[\begin{array}{ll}
\mathbf{x}^{\top} & \dot{\mathbf{x}}^{\top}
\end{array}\right]^{\top}=-\left(\mathbf{F}_{\mathrm{x}} \mathbf{X}+\mathbf{F}_{\mathrm{v}} \dot{\mathbf{x}}\right) \\
\mathbf{F}_{\mathrm{x}}, \quad \mathbf{F}_{\mathrm{v}}: \mathrm{N} \times \mathrm{N} \text { 行列 }
\end{gathered}
$$

この行列 $\mathbf{F}_{x}, \mathbf{F}_{v}$ の各要素 $F_{x i, j}, F_{v i, j}(i, j=1,2, \cdots N)$ を Fig. 5 に示す. Fig. 5 より, 制御力の決定には特定の変位成分が大きく関係して おり, 速度成分の影響は小さいことがわかる， $\mathbf{F}_{x}$ の大きな成分は対 角およびそれに平行な並びに沿って分布しており，各並びについて 成分の絶対值の平均が $10^{6}$ を上回る並びを取り出し $\mathbf{F}_{\mathrm{x}}^{\prime}$ とすると, 次 のように表すことができる.

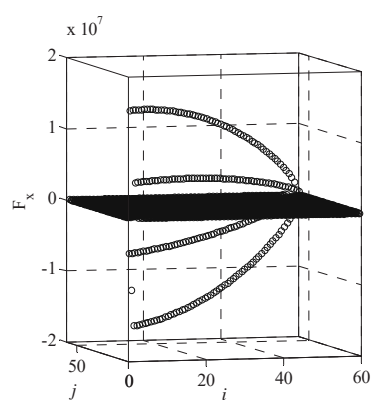

(a) $F_{x}$

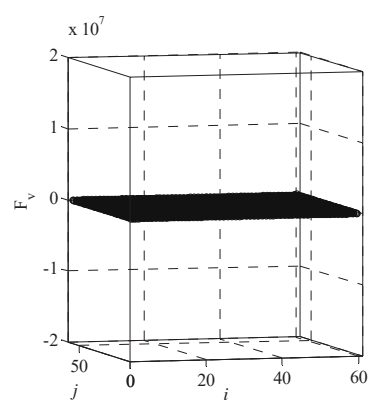

(b) $F_{v}$
Fig. 5 Feedback gains

$$
\mathbf{F}_{\mathrm{x}}^{\prime}=\mathbf{F}_{\mathrm{a}}+\mathbf{F}_{\mathrm{b}}+\mathbf{F}_{\mathrm{c}}+\mathbf{F}_{\mathrm{d}}
$$

$\mathbf{F}_{\mathrm{a}}=\left[\begin{array}{lll}\mathrm{F}_{11} & & \mathbf{O} \\ & \ddots & \\ \mathbf{O} & & \mathrm{F}_{\mathrm{NN}}\end{array}\right]$

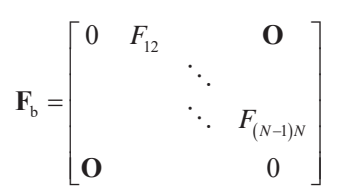

$\mathbf{F}_{\mathrm{c}}=\left[\begin{array}{cccc}0 & & & \mathbf{O} \\ \mathrm{F}_{21} & \ddots & & \\ & \ddots & \ddots & \\ \mathbf{O} & & \mathrm{F}_{\mathrm{N}(\mathrm{N}-1)} & 0\end{array}\right]$

$$
\mathbf{F}_{\mathrm{d}}=\left[\begin{array}{ccccc}
0 & & & & \mathbf{O} \\
0 & \ddots & & & \\
\mathrm{F}_{31} & \ddots & \ddots & & \\
& \ddots & \ddots & \ddots & \\
\mathbf{O} & & \mathrm{F}_{\mathrm{N}(\mathrm{N}-2)} & 0 & 0
\end{array}\right]
$$

これらの各要素を再び 3 次元グラフ化したものが Fig. 6(a)であり， 
$\mathbf{F}_{\mathrm{a}}$ および $\mathbf{F}_{\mathrm{d}}$ の要素は常に負の值をとっていることがわかる．また， Fig. $6(\mathrm{~b})$ は各行列の $\mathrm{i}$ 列の 0 でない成分 $\left(\mathrm{F}_{\mathrm{ai}}, \mathrm{F}_{\mathrm{bi}}, \mathrm{F}_{\mathrm{ci}}, \mathrm{F}_{\mathrm{di}}\right)$ の 絶対值をグラフ化したものであり, $\left|\mathrm{F}_{\mathrm{ai}}\right|$ と $\left|\mathrm{F}_{\mathrm{ci}}\right|,\left|\mathrm{F}_{\mathrm{bi}}\right|$ と $\left|\mathrm{F}_{\mathrm{di}}\right|$ の值はほ ぼ同じ大きさをとっている，このとき，制御力 $u_{i}$ は式(32)のように 近似することができる.

$$
u_{i}= \begin{cases}F_{a i} x_{i}+F_{b i+1} x_{i+1} & (i=1) \\ F_{c i-1} x_{i-1}+F_{a i} x_{i}+F_{b i+1} x_{i+1} & (i=2) \\ F_{d i-2} x_{i-2}+F_{c i-1} x_{i-1}+F_{a i} x_{i}+F_{b i+1} x_{i+1} & (i=3, \cdots, N-1) \\ F_{d i-2} x_{i-2}+F_{c i-1} x_{i-1}+F_{a i} x_{i} & (i=N)\end{cases}
$$

Fig. 6(b)より, $\quad \mathrm{i} \geq 3$ において $\left|\mathrm{F}_{\mathrm{ai}}\right| \simeq\left|\mathrm{F}_{\mathrm{c} i}\right|, \quad\left|\mathrm{F}_{\mathrm{bi}}\right| \simeq\left|\mathrm{F}_{\mathrm{di}}\right|$ であるので, Fig. 6(a)の符号を考慮し $-\mathrm{F}_{\mathrm{ai}}=\mathrm{F}_{\mathrm{ci}}=\mathrm{a}_{\mathrm{i}}, \quad \mathrm{F}_{\mathrm{bi}}=-\mathrm{F}_{\mathrm{di}}=\mathrm{b}_{\mathrm{i}} \quad\left(\mathrm{a}_{\mathrm{i}}>\mathrm{b}_{\mathrm{i}}\right)$ とお くと，式(33)のようにまとめることができる.

$u_{i}=-b_{i-2} x_{i-2}+a_{i-1} x_{i-1}-a_{i} x_{i}+b_{i+1} x_{i+1} \simeq-a\left(x_{i}-x_{i-1}\right)+b_{i+1} x_{i+1}-b_{i-2} x_{i-2}$
$(i=3, \cdots, N-1)$

ここで, Fig. 6(b)より $\mathrm{i} \geq 3$ において $\left|\mathrm{F}_{\mathrm{ai}}\right| \simeq\left|\mathrm{F}_{\mathrm{ci}-1}\right|$ なので, これをa と した。式(33)に含まれる $\left(\mathrm{x}_{\mathrm{i}}-\mathrm{x}_{\mathrm{i}-1}\right)$ は，第 $\mathrm{i}$ 層の層間変位であること から，制御力はアクティブブレースの設置される層の層間変形に大 きく依存すると考えられる.また, 振動モード形状（以降，モード） の節では層間変形が大きいため，モードの節の位置にブレースを配 置した場合の結果が効果的となったと考えられる.

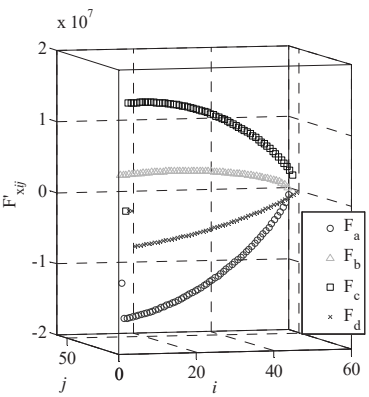

(a) The components of $\mathbf{F}_{x}^{\prime}$ matrix.

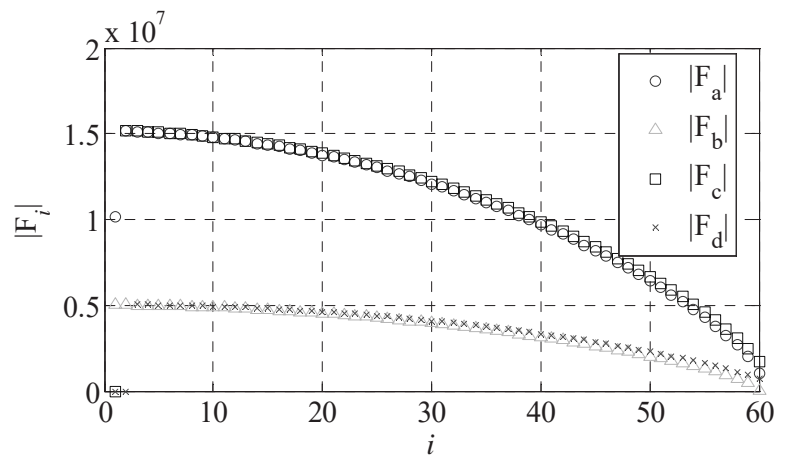

(b) Absolute value of each components of $\mathbf{F}_{x}^{\prime}$ matrix

Fig. 6 Values of each matrix

\section{5. 新規配置法の提案}

\section{1 提案配置法}

4 章において, アクティブブレースの制御力は建物の層間変位に 依存し, 層間変位が増大寸ると予想される層付近に配置すると高い 制振効果が得られるのではないかと予想した。 そこで, 制御対象の 振動モード形状より層間変位が増大寸ると予想される位置を特定し, その位置を基準としてアクティブブレースを配置する方法を新規配 置法として提案する.

層間変位が増大寸る点として, モードの層間変形が増大する位置 を基準としてアクティブブレースを配置する MSD を作成した. MSD の作成において基準とする層は, $\mathrm{n}$ 次モードベクトルの $\mathrm{i}$ 要素 $\varphi_{\mathrm{n}}(\mathrm{i}) \quad(\mathrm{n}=1,2,3)$ および $\varphi_{\mathrm{n}}(0)=0$ を用いて $\mathrm{i}=1,2, \cdots \mathrm{N}$ について $\left|\varphi_{\mathrm{n}}(\mathrm{i})-\varphi_{\mathrm{n}}(\mathrm{i}-1)\right|$ を計算し, その局所極大となる $\mathrm{i}$ を選択する. ただ し, 同一の $\mathrm{i}$ を複数のモードで重複して取り出すことはない. 同時 に，実際の建物に適用する場合等の篇密なモードを算出することが 難しい場合を考え, モードの節を基準とする NOD を作成し，これ ら 2 つの配置法において差が生じるか検証を行うものとする。モー ドの節とする位置の要素 $\mathrm{i}$ は, $\left|\varphi_{\mathrm{n}}(\mathrm{i}+1)\right|>\left|\varphi_{\mathrm{n}}(\mathrm{i})\right| \cap \varphi_{\mathrm{n}}(\mathrm{i}) \varphi_{\mathrm{n}}(\mathrm{i}+1)<0$ $(\mathrm{i}=1,2, \cdots, \mathrm{N}-1)$ を満たす.

· MSD : モードの層間変形基準

・ NOD : モードの節基準

本論では, 高次モードが低次に比べ卓越しない事および，4 次以 降のモードで配置される位置は 1～3 次でおおよそカバーできるこ とから, 基準とするモードの次数は $1 \sim 3$ 次とした.

ただし, 本論では建物をせん断質点系でモデル化し, 振動モード もせん断系に限られる．曲げを考慮する場合はモード形状にも曲げ が表れるため，適切な配置が異なってくる可能性がある。

\section{2 性能検証}

配置するアクティブブレースの総数を 10 とした場合について応 答の比較を行った。それぞれのアクティブブレースの配置について Table 3 にまとめる. 入力波には,

· 2004 年新潟県中越地震 K-NET 新宿観測記録 NS 成分

（最大加速度：0.15 $/ \mathrm{s}^{2}$ )（新宿波）

- 2011 年東北地方太平洋沖地震 K-NET 名古屋観測記録 NS 成分 （最大加速度 : $0.11 \mathrm{~m} / \mathrm{s}^{2}$ ) (名古屋波)

の 2 種類を用いた．新宿波および名古屋波はそれぞれ建物の 1 次お よび 2 次の固有周期近傍に卓越成分を持つ長周期地震動である。ま た, 制御力の上限を Mastali らの研究 8)を参考に $1000 \mathrm{kN}$ とし, 制 御力の重み $R$ は建築基準法告示に示された加速度応答スペクトルを 持つ稀に起こる地震動（以下，告示波と示す）を入力した場合の最 大制御力が $1000 \mathrm{kN}$ を上回らないよう設定した. なお, 制御力が $1000 \mathrm{kN}$ を上回る場合は $1000 \operatorname{sign}\left(\mathrm{u}_{\mathrm{i}}\right)$ が入力されるものとする. 結 果を Fig. 7, Fig. 8 に示す.

Table 3 Placement of active braces (proposed methods)

\begin{tabular}{|l|l|}
\hline MSD & $1,2,3,30,31,52,53,54,56,57$ \\
\hline NOD & $1,2,3,29,30,44,45,46,52,53$ \\
\hline
\end{tabular}




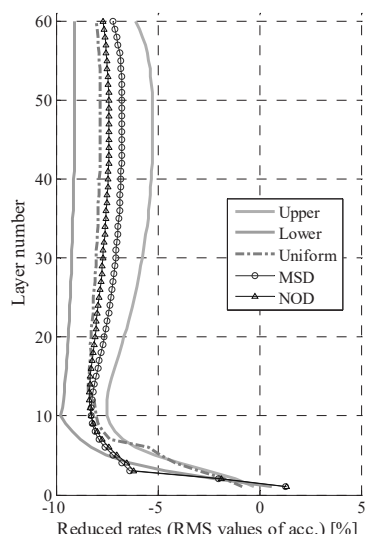

(a) RMS values of acceleration as reduced ratio to without control case

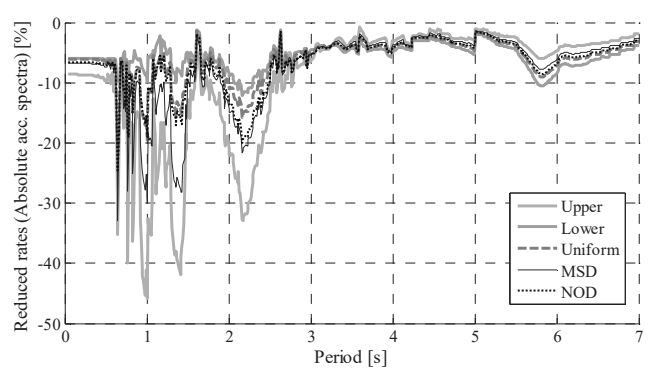

(d) Acceleration response spectra as reduced ratio to without control case

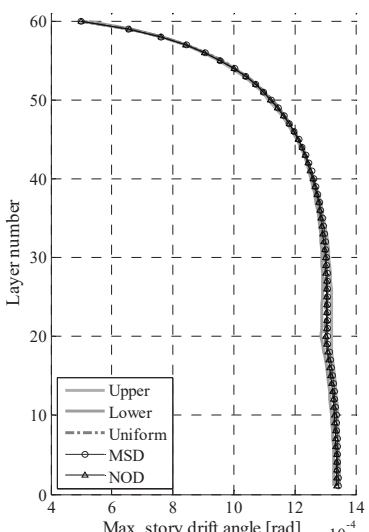

Max. story drift angle [rad] $\times 10^{-4}$

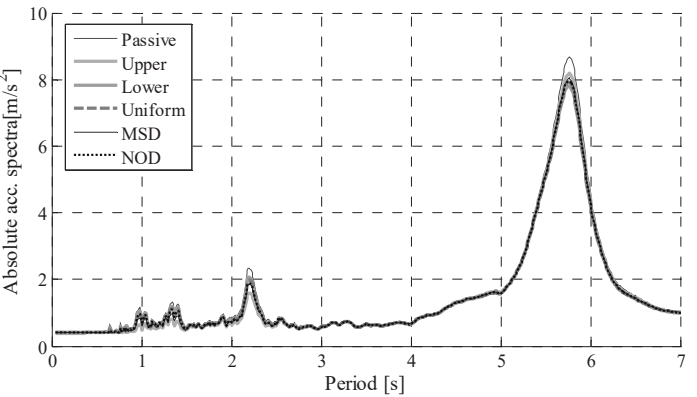

(c) Absolute acceleration spectra

(b) Max. story drift angle

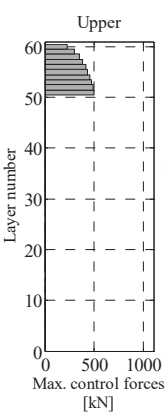

$[\mathrm{kN}]$
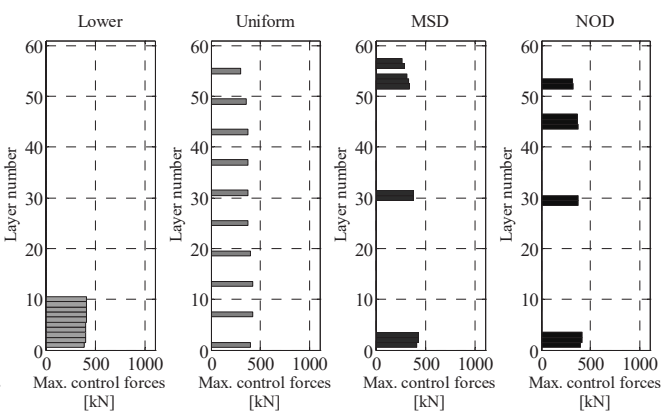

(e) Max. control forces

Fig. 7 Compared results (Shinjuku)

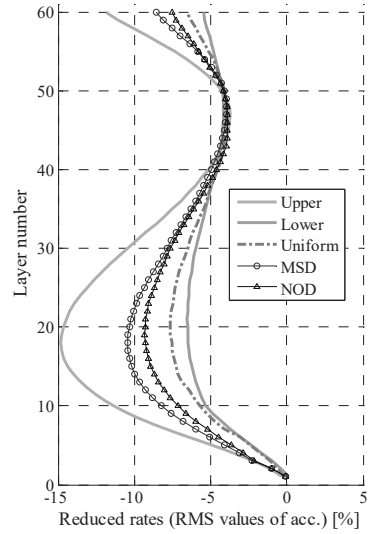

(a) RMS values of acceleration as reduced ratio to without control case

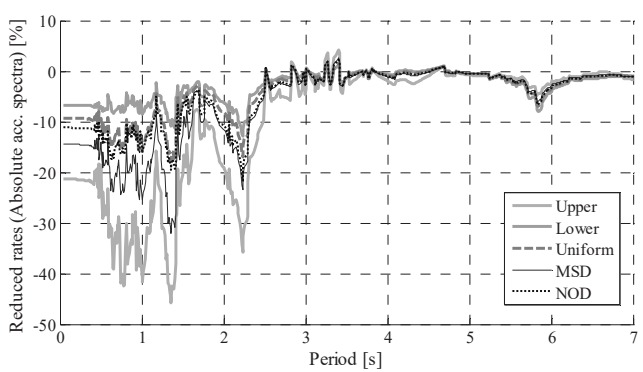

(d) Acceleration response spectra as reduced ratio to

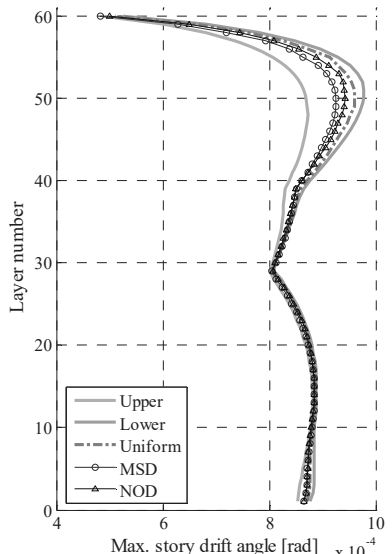

(b) Max. story drift angle

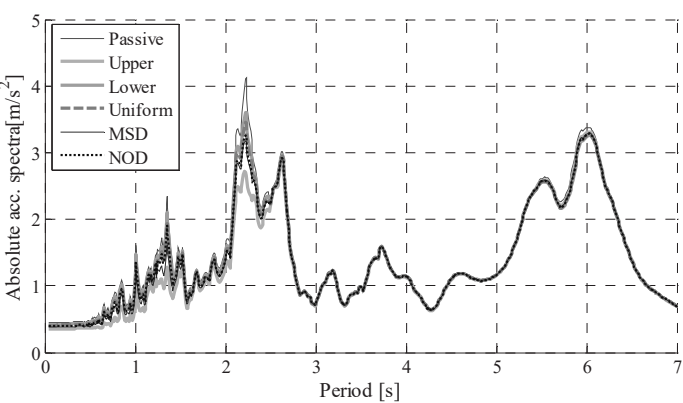

(c) Absolute acceleration spectra
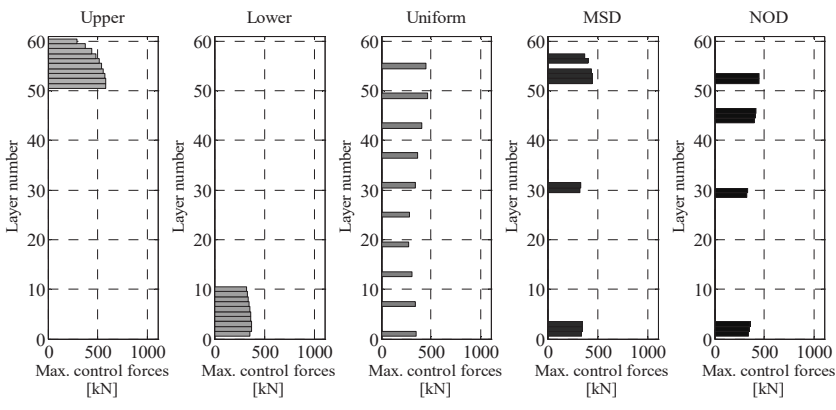

(e) Max. control forces

without control case

Fig. 8 Compared results (Nagoya) 
Fig. 7(a) および Fig. 8(a) に各層の加速度応答の RMS 值を非制 御時に対する比率で示す。応答低減効果を比較すると新宿波を入力 した場合には Lower 配置の効果が高く, 名古屋波を入力した場合に は Upper 配置の効果が高い. 提案配置法 MSD および NOD は 2 つ の入力でともに中程度の効果を示している. MSD と NOD を比較す ると，新宿波に対しては低減度は最大でいずれも $8 \%$ ほどとなって いるが，中層から高層部にかけては NOD の方が高い効果を示して いる. 名古屋波に対しては，低減度は最大で MSD が約 10\%，NOD が約 9\%と，MSD の方が高い効果を示している． Fig. 7(b) および Fig. 8(b) は各配置法における最大層間変形角を示しており,いずれ の配置法においても最大值が $1 / 200$ 以下に収まっていることから, 建物の安全を確保できる範囲であることがわかる.応答の低減度は, 1 次に対してはいずれの配置法においても大きな差は見られないが, 2 次に対しては上層付近において応答の差が大きくなっている，最 も高い効果を示したのは Upper であり，50 層付近では約 $8.5 \times 10^{-4}$ $\mathrm{rad}$ と他の配置法より応答が小さくなっている. Fig. 7(c) および Fig. 8(c) は各配置法における加速度応答スペクトルを示している. アクティブブレースを配置した場合にはいずれの場合においても， 建物単体の場合よりも固有周期付近における応答が減少している. 各配置法における最上層加速度の加速度応答スペクトルを求め, 非 制御時と比較した結果を Fig. 7(d) および Fig. 8(d) に示す.これよ り, Upper 配置は短周期成分に対して最大で約 $45 \%$ 減少と効果は 高いものの，1 次固有周期（5.8 秒）成分に対する効果は他より小さ い.また，Lower 配置の場合は 1 次固有周期成分に対する効果は最 大で約 $10 \%$ 低減と高いものの，2 次以降（2.2 秒，1.4 秒，…) の成 分については他の配置法を下回っている. MSD およびNOD につい ては，効果の最大比較においては Upper および Lower には及ばな いが，これらの中間を取っていることから，提案配置法ではより広 い周期帯域に対応でき， 1 次および 2 次固有周期成分を多く含む長 周期地震動に対しても効果的と考える.

各配置法における最大制御力を Fig. 7(e)および Fig. 8(e)に示す. 各配置法における制御力は大部分において同程度入力されているも のの, Upperの最上層付近においては他と比較して入力が小さくな っている.これより, 最上層付近におけるアクティブブレース付加 の効果は小さいと考えられる.

\section{6. 故障に対するロバスト性の比較}

アクティブブレースの配置数を 10 基とした場合について, 故障 が生じあるアクティブブレースが停止した場合（以降，故障と呼ぶ） のロバスト性の比較を行う.

地震動の入力から 10 秒後に配置されたアクティブブレースのう ち 1 基が故障を起こし, 制御力を発揮できなくなることを想定して, 故障が起きない場合からの制振効果の低下を比較した.

応答比較を行う配置法は, 提案配置法の MSD と NOD, 4.1 節で 検討した 4 種類の単純配置法の 1 つである Uniform とした. Uniform は対応可能な周期帯が限定されず, また, アクティブブレ ースが間隔をあけて配置されているため, 故障により他のアクティ ブブレースに与える影響が小さく, 応答の悪化が小さくなると考え 選択した．アクティブブレースの配置されている層は配置法ごとに 異なるため (Table 2, Table 3 参照), 故障の生じる層は下層, 中層,
上層からそれぞれ $1 ， 30 ， 55$ 層に近い位置を Table 4 のように設定 した.

Table 4 Position of a failure active brace

\begin{tabular}{|l|r|r|r|}
\hline Failure position & \multicolumn{1}{|c|}{ Uniform } & \multicolumn{1}{|c|}{ NOD } & \multicolumn{1}{c|}{ MSD } \\
\hline Upper floor & 55 & 54 & 53 \\
\hline Middle floor & 31 & 30 & 30 \\
\hline Lower Floor & 1 & 1 & 1 \\
\hline
\end{tabular}

地震動入力には制御力の重みを決定するために用いたものと同じ告 示波を用いた. 結果を Fig. 9〜 Fig. 11 に示す.

通常時および故障時の最大制御力を Fig. 9〜Fig. 11 の(b)に示す. これより, 各配置法において故障の生じる層に加えられる最大制御 力は減少し, それに隣接する層における最大制御力が増大している ことが読み取れる. 故障箇所付近において正常に機能しているアク ティブブレースの基数は, Uniform では間隔をあけて配置している ためいずれの条件においても 0 基となる. MSD および NOD では, 下層故障では 2 基，中層故障では 1 基，上層故障では MSD では 4 基，NOD では 1 基が残る.

Fig. 9(a)より, Uniform は下層で故障が発生した場合には，下層 での応答の悪化は約 $0.40 \%$ とSD および NOD よりも小さいもの の, 中層および上層での応答の悪化は約 $0.75 \%$ と大きい. MSD お よび NOD はさほど大きな差はなく, 悪化度は約 $0.50 \%$ となってい る。一方， Fig. 10(a) Fig. 11(a)より，中層および上層において故 障が発生した場合には，Uniform は最大で約 $1.80 \%$ 悪化と MSD お よびNOD よりも悪化が大きいため, Uniform のロバスト性は提案 配置法よりも低いと考えられる. Uniform と比較して提案配置法の ロバスト性が高くなった理由として, 提案配置法は層間変形の増大 する層を予想しアクティブブレースを配置しているため, 故障が発 生した場合でも有効な層周辺に配置された基数が多く, 故障が発生 した場合でも応答の悪化が小さくなったと考えられる.

MSD と NOD を比較すると, 中層で故障が発生した場合では大き な差は見られない。しかし，上層において故障が発生した場合の応 答の悪化は, MSD が最大で約 $1.1 \%, \mathrm{NOD}$ が最大で約 $1.2 \%$ と MSD の方が小さくなっている.

NOD よりも MSD の方が応答の悪化が小さくなった理由として は，MSD は振動モード形状より求めた層間変形を基準として配置 層を決定しているため，節位置から決定した NOD よりもアクティ ブブレースが効果的に機能したと考えられる．また，故障の生じた 周辺に残るアクティブブレースの基数が MSD の方が多いため, こ れも影響していると考えられる。 


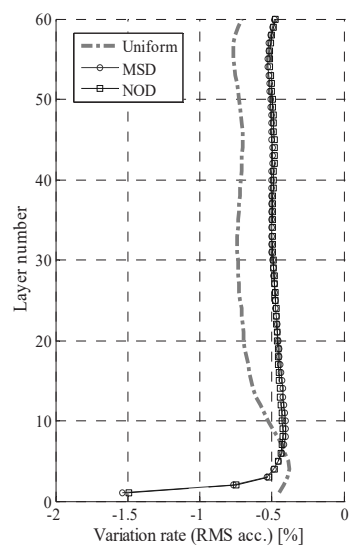

(a) RMS values of acceleration as deterioration ratio to no failure
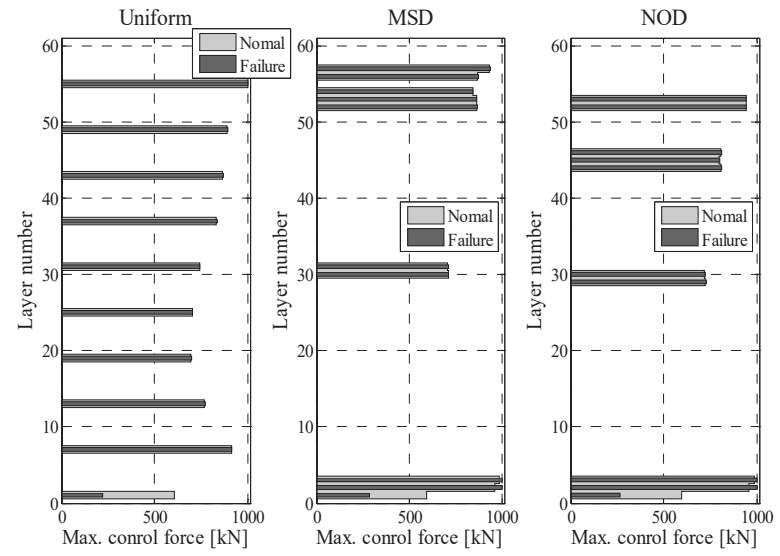

(b) Max. control force

Fig. 9 Robustness comparison results (Failure at lower layer)

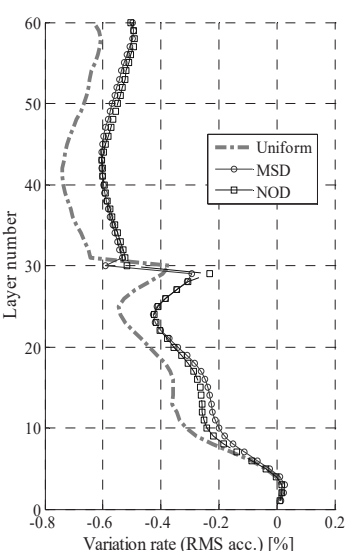

(a) RMS values of acceleration as deterioration ratio to no failure
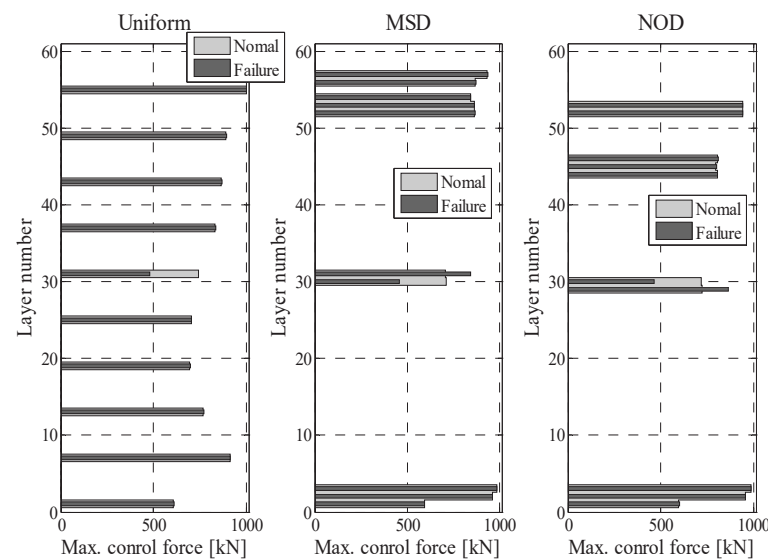

(b) Max. control force

Fig. 10 Robustness comparison results (Failure at middle layer)

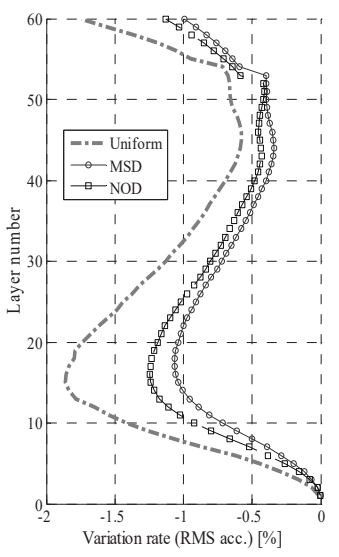

(a) RMS values of acceleration as deterioration ratio to no failure
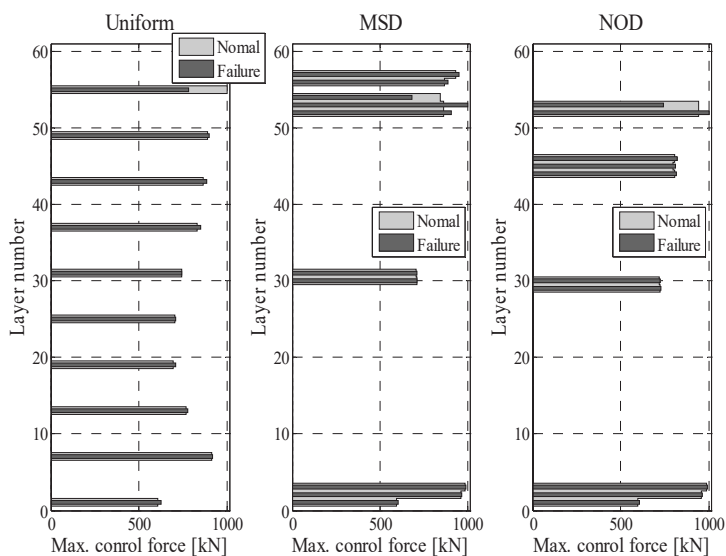

(b) Max. control force

Fig. 11 Robustness comparison results (Failure at upper layer)

\section{7. 結言}

本研究では超高層建物に対するアクティブブレースの最適配置法 を提案した.

まず 4 種類の単純配置法（上層集中・中層集中・下層集中・等間 隔配置）を用いた制振効果の比較を行い，アクティブブレースの制
御力は主にアクティブブレースを設置した層の層間変位に依存して 決定されるという傾向を示した. 次に, 建物の各次振動モード形状 を求め, 層間変位の増大寸る層を推定し, 新たに配置法 MSD およ びNOD を提案した。建物の 1 次および 2 次固有周期成分を多く含 む地震動を用いた検証を行った。 その結果, 1 次成分の卓越した地 
震動に対しては Lower が最大約 10\%低減，2 次成分の卓越した地 震動に対してはUpper が最大約 $15 \%$ 低減と最も高い効果を示した. しかし，これらは高い効果を示した周期帯域を外れると制振効果が 他の配置法を下回っていることから，対応可能な周期帯域が限られ ると考えられる. 提案配置法は 1 次成分の卓越した地震動に対して はいずれも約 8\%, 2 次成分の卓越した地震動に対しては MSD が最 大約 10\%, NOD が最大約 9\%という結果となった。これは各地震 動に対して Upper および Lower の中程度の効果であり, 提案配置 法ではより広い周期帯域に対応が可能と考えられる.

次に, 配置されたアクティブブレースのうち 1 基が故障により制 御力を発揮しなくなった場合を想定し，故障が起きない場合からの 応答の悪化率を比較した。下層および中層で故障が生じた場合には MSD およびNOD はいずれも中層から高層にかけて約 0.5\%程度悪 化と大きな差は生じなかった。高層で故障が発生した場合には， NOD が最大約 $1.2 \%$, MSD が最大約 $1.1 \%$ 悪化という結果が得られ た.これらは比較に用いた Uniform の結果と比較して悪化度が小さ く，故障に対するロバスト性が優れているといえる．提案配置法で は層間変位が増大寸ると予想される層を基準として配置場所を決定 しているためと考えられ，特に振動モード形状の層間変位を基準と した MSD においては応答の悪化が小さくなることを示した.

今後の課題として, 本論では建物 1 層に配置するアクティブブレ 一スの最大数を 1 基として解析を行っているが，より高い制振効果 を実現できるよう複数基配置する場合についての検討が挙げられる. また，本研究ではアクティブブレースの制御力の重みを告示波を基 準として決定しており，アクティブブレースの制御遅れについても 考慮していないため, 設計に適した地震動の作成および遅れを考慮 した最適化が挙げられる.

\section{謝辞}

本研究では，防災科学技術研究所 K-NET および KiK-net の地震 観測記録を用いた。記して謝意を表する。

\section{参考文献}

1) Japan Elevator Association: Chibaken hokuseibu jishin wo keiki tosuru jishintaioukyoukasaku kentou - shoukouki taishinsekkei sekoushishin no minaoshi - (Examination about Corresponding Measures to Strengthen for Earthquake from the Earthquake of Northwestern Chiba-Review of Seismic Design of Elevator and Construction Guidelines-), Elevator Kai, 2006.1 (in Japanese) 社団法人日本エレベーター協会，「千葉県北西部地震」を契機とする地 震対応強化策検討一昇降機耐震設計・施工指針の見直し一, エレベータ 界, 2006.1

2) "Sakishima Chousha no annzennseinado nitsuiteno kennshoukekka (Verification Result about Safety and so on of Sakishima Government Office)", General Affairs Department of Osaka, 2011.5 (in Japanese) http://www.pref.osaka.lg.jp/attach/13203/00073224/110512sakisimaa nzenkensyo.pdf (accessed 2016-06-03)(in Japanese) “咲洲庁舎の安全性等についての検証結果”, 大阪府総務部, 2011.5

3) Tzan, S.R. and Pantelides, C.P.: Convex model for seismic design of structures - II : Design of conventional and active structures, Earthquake Engineering and Structural Dynamics, Vol.25, No.9(1996.9), pp.945-963.

4) Cimellaro, G.P., Soong, T.T., and Reinhorn, A.M.: Integrated Design of Controlled Linear Structural Systems, Journal of Structural Engineering, Vol.135, No.7, pp.853-862, 2009.7

5) Cimellaro, G.P., Soong, T.T., and Reinhorn, A.M.: Integrated design of inelastic controlled structural systems, Structural Control and Health Monitoring, Vol.16, Nos.7-8(2009.11-12), pp.689-702.

6) Kohiyama, M. and Horiguchi, C.: Simultaneous Optimization of Structural and Control Systems of A Multi-Story Building with PD Controlled Active Braces Using Design Response Spectra, Journal of Structural and Construction Engineering (Transactions of AIJ) Vol. 78, No.683, pp.71-80, 2013.1 (in Japanese)

小檜山雅之, 堀口知宏：PD 制御アクティブブレースを有する多層建物の 設計用応答スペクトルを用いた構造系・制御系の同時最適化，日本建築 学会構造系論文集, 第 78 巻, 第 683 号, pp.71-80, 2013.1

7) Baba, T. and Kohiyama, M.: Seismic Response Control of a Building and Elevator Rope with Active Mass Damper, Theoretical and Applied Mechanics Japan, Vol.58, pp.19-30, 2010

8) M. Mastali, A. Kheyroddin, B. Samali and R. Vahdani: Optimal placement of active braces by using PSO algorithm in near- and far-field earthquakes, International Journal of Advanced Structural Engineering, Vol.8, pp.29-44, 2016 


\title{
VIBRATION CONTROL OF HIGH-RISE BUILDING USING ACTIVE BRACES AND THEIR OPTIMAL PLACEMENT
}

\author{
Minori UEDA ${ }^{* 1}$, Nanako MIURA ${ }^{* 2}$ and Akira SONE ${ }^{* 3}$ \\ ${ }^{* 1}$ Grad. Student, Dept. of Mechanical Engineering, Kyoto Institute of Technology \\ ${ }^{* 2}$ Assist. Prof., Faculty of Mechanical Engineering, Kyoto Institute of Technology, Dr.Eng. \\ ${ }^{*}$ Prof., Faculty of Mechanical Engineering, Kyoto Institute of Technology, Dr.Eng.
}

These days, there are a lot of high-rise buildings and it is important for these buildings to be reinforced against earthquakes. As a device to reduce the response of the building, active braces are used. In this paper, their optimal placement method to reduce building's response by limited number of them is researched.

Firstly, to search optimal placement to set active braces, response comparisons of four setting patterns, which are named Upper, Lower, Middle and Uniform, are carried using sine waves. These sine waves have the same periods with natural periods of the building. It shows that control forces become large at layers which story drifts are large. Thus, the values of the feedback gain matrix on Linear Quadratic Regulator (LQR) method are compared. It appears that the feedback gain matrix has large gains where they are related to displacement. In addition, equation of control force shows each layer's story drift has a great influence on deciding control forces.

Secondary, setting methods named MSD and NOD are proposed and their effectiveness is verified. MSD places active braces around the layers which will have large story drift and NOD places them around nodal points. In this paper, two earthquakes which have large power on building's 1 st or 2nd natural period are used. It is confirmed that Lower pattern is effective for the 1st mode earthquake, but against the 2nd mode earthquake, Upper pattern is more effective. So these setting patterns can't work effectively for all earthquakes. About MSD and NOD pattern, though their effectiveness aren't the best, but they can reduce responses against several frequencies. This means that they can work more effectively for several types of earthquakes.

Thirdly, to research the safer setting method, the robustness is compared when one active brace breaks down at upper, lower or middle layer. In this paper, three setting patterns, MSD, NOD and Uniform, are used to compare. On almost all of the layers, responses of Uniform became larger than MSD and NOD when the break down happened. From the comparison of MSD and NOD, when the break down happened at lower and middle layer, responses of each layer don't show large difference. But the case when the break down happened at upper layer, responses of NOD pattern became larger than that of MSD pattern. It means MSD pattern has more active braces at effective layers than NOD.

In this paper, effectiveness comparison on four simple patterns shows that control forces become large at the layers which have large story drift. To research their relationship, the feedback gain matrix is researched. Control forces are decided from the displacements and velocities of each layer and displacements have larger influence. From this relation, two setting patterns, named MSD and NOD, are proposed and comparison of their effectiveness and robustness were carried. Results shows that MSD and NOD can reduce responses on some modes, thus they will work more effectively for many type of earthquakes. In addition, MSD has better effectiveness than NOD when break down happens.

In future studies, advanced setting pattern which has some active braces for each selected layer will be researched. In addition, optimal control design which considers many types of earthquakes including imitation wave and time lag between earthquake input and control force are needed to research. 